\begin{tabular}{c} 
Volume and Issues Obtainable at Center for Sustainability Research and Consultancy \\
Journal of Accounting and Finance in Emerging Economies \\
ISSN: 2519-0318 ISSN (E) 2518-8488 \\
Volume 4: Issue 1 June 2018 \\
CSRᄃ \\
Journal homepage: $\underline{\text { www.publishing.globalcsrc.org/jafee }}$ \\
\hline
\end{tabular}

\title{
King's Model on Capitalization under Basel III: The Case of Lebanese Banks
}

\author{
${ }^{1}$ Somaya Nasif El Ahmadieh, ${ }^{2}$ Nabil Georges Badr \\ ${ }^{1}$ Faculty of Business Administration, GGSB, France. sarta505@hotmail.com \\ ${ }^{2}$ Faculty of Business Administration, GGSB, France. nabil.badr@alumni.grenoble-em.com
}

\begin{tabular}{l}
\hline ARTICLE DETAILS \\
\hline History \\
Revised format: May 2018 \\
Available online: June 2018 \\
\hline Keywords \\
Capital Adequacy Ratios, \\
Lending Spread Ratio, \\
Financial Crisis, Commercial \\
Banks In Lebanon
\end{tabular}

\section{JEL Classification:}

F20,F34,F30,F13

\begin{abstract}
Objective: Lebanese banks have shown immunity towards the 2008 financial crisis that was attributed to many factors including a strong regulatory and supervisory system of conservative practices and structural economic factors such as the recurrence and non-speculative nature of capital inflows towards Lebanon supported by a large pool of offshore savings from diaspora and investors around the globe. The purpose of this study is to investigate the relation between capital adequacy ratios (CARs) and lending spread ratio (LSR). This paper presents the first assessment of the Basel III capital requirements on lending spread ratio before, during and after the financial crisis among commercial banks operated in Lebanon.

Methodology: We consider King's approach and assess his model's applicability in the Lebanese context. Findings indicate some deviations, specifically related to the practices and financial performance of commercial banks in Lebanon.

Results: We found no indication of impact of the change in CAR on LSR among Lebanese commercial banks in years prior to the recent financial crises; Nevertheless, the impact of changing CAR by 1 pp on LSR has a modest effect on Lebanese commercial banks during the years of financial crises; this effect is lowered to become modest after the crisis.

Implication: The results of the current study reveal significant implications for managers in commercial banks in particular and all banks in general. Given that Lebanese commercial banks are well-capitalized and their Capital Adequacy Ratios are above international benchmarks, bank managers must carefully monitor the cost of the implementation of Basel III requirements.
\end{abstract}

(C) 2018 The authors, under a Creative Commons AttributionNonCommercial 4.0

Corresponding author's email address: $\underline{\text { sarta505@ hotmail.com }}$

Recommended citation: Ahmadieh, S. N., Badr, N.G. (2018). King's Model on Capitalization under Basel III: The Case of Lebanese Banks. Journal of Accounting and Finance in Emerging Economies, 4(1) 77-94

DOI: $10.26710 /$ jafee.v4i1.347

\section{Introduction}

After the onset of the financial crisis of 2008, commercial banks are obliged to hold capital buffers against any potential risk of decline in credit quality of the counterparty. On December 2010, the Basel Committee on Banking Supervision released two frameworks that regulate liquidity risk measurement, standards and monitoring and published a new regulatory reform entitled "Basel III". The new reform aimed to strengthen banking regulation, supervision and risk management. As a result, banks must hold a minimum level of capital which places pressures on banks' performance, especially in developed countries. Banks have, since then, introduced a myriad of initiatives that compensate for the cost of higher 
capital by reducing operating expenses and/or increasing income (particularly non-interest income). Other initiatives seek to reduce the cost of holding higher capital by transferring some of its sum to the end customers in the form of higher lending spread (Elliott, 2010; King, 2010, etc...). These initiatives manipulate industry defined performance indicators to strike a balance between regulatory and performance requirements. The study explores consequences of these initiatives, as well as it aims to provide bankers with sufficient evidence to take suitable decisions and formulate strategies which may result in optimal profit.

The capital adequacy ratio (CAR) represents the reserves to guard a bank against the credit risk, operational risk and market risk (Mahajan et al, 2012). Even though Basel III maintains the Capital Adequacy Ratios (CARs) at its minimum level $8 \%$ as set by Basel I, a bank must increase Capital Adequacy Ratios to sustain its stability (Berger et al, 1995), to achieve increase in its profitability (Athanasoglou, Brissimis, \& Delis, 2008), and to cover risk by holding minimum Capital Adequacy Ratios (Bilal and Salim, 2016). The contraction on capital imposed by the latest regulation issued by the Basel Committee on Banking Supervision (Karim, Hassan, Hassan \& Mohamad, 2014) increases banks' lending problems, by causing difficulties in meeting capital requirements; and affects critically bank performance (Peek and Rosengren, 1995). In fact, the evidence supports that the bank's manager seeks to reduce the cost of holding higher CARs by transferring some of it to the end customers in the form of higher LSR (Elliott, 2009; King, 2010, etc...).

\subsection{The Lebanese Banking Sector}

The Lebanese banking sector is represented by the Central Bank, Banque du Liban (BDL), fifty three commercial banks (70\%), eighteen investment banks (24\%), and five Islamic banks (6\%) (Association of Banks in Lebanon, 2015).

Commercial banks are the main provider of credit to individuals as well as businesses (Association of Banks in Lebanon, 2015). These banks are required to provide medium and long-term credit for real estate, industry, agricultural development and household lending. Lebanese banks have shown immunity towards the latest financial crisis that was attributed to many factors including a strong regulatory and supervisory system of conservative practices and structural economic factors such as the recurrence and non-speculative nature of capital inflows towards Lebanon supported by a large pool of offshore savings from diaspora and investors around the globe. Though Lebanon is not a member of the BCBS, Banque du Liban (BDL), Lebanon's central bank, mandated on Lebanese banks to comply with the standards issued by the BCBS. Lebanon is an interesting case study because Lebanese banks have shown some resilience toward the financial crisis, primarily due to their traditionally conservative approach to speculation in subprime mortgages and in any other risky packages of structured products and bundled-up debt, to liquidity requirement with an average liquidity ratio of $40 \%$ (Naimy, 2011), and to the introduction of the bank merger law, that forces weak banks to merge with strong ones. In line with the importance of capital regulation for banking organizations, the aim of the current paper is to explore the behavior of the CARsLSR relationship, and to add to the body of knowledge on banking industry in this important issue by answering the following research question: "To which extent do the implementation of Basel III capital requirements impact on lending spread ratio in the commercial banks operated in Lebanon?

\section{Literature Review}

\subsection{Basel Accord}

Since the establishment of Basel Committee on Banking Supervision in 1974 in Basel city in Switzerland, the committee has issued the standards and regulations that put emphasis on banks' capital, to ensure that capital is sufficient to cover unexpected risks. Accordingly, the standards issued by the Basel Committee on Banking Supervision (BCBS) are constituted of three successive accords to improve the resilience of banking organizations:

Basel I: In December 1988, the Committee released its first proposition Basel I: "The International Convergence of Capital Measurement and Capital Standards" (BCBS, 1988). Basel I accord focused on 
credit risk and designed to enhance capital profile. The minimum capital requirements for a bank is set at $8 \%$ of its risk-weighted assets to measure riskiness associated with bank's assets (Dermine, 2014). Bank's capital are divided into two parts, including core capital "Tier I capital or equity capital" and supplementary capital "Tier II capital” (Huang and Pan, 2016).

Basel II: In June 2004, Basel II was released and adopted across countries from the beginning of year 2006; Even though, the CAR of Basel II was kept the same as in Basel I, the more sophisticated methodologies imposed under Basel II accord might decrease the capital that banks are obliged to hold against various types of credit risk (Brownbridge, 2015). In addition to dimensions of credit risk, Basel II has improved by incorporated market and operational risks. Though an improvement on its predecessor, this sequel was not enough to prevent the recent banking downfall (Krishnan and Sukar, 2014).

Basel III: In response to the recent financial crisis of 2007-2008, the BCBS released on December 2010 two frameworks that further regulate liquidity risk measurement, standards and monitoring (Curry, Feldman, \& Johnson, 2012); namely, 'Basel III: A global regulatory framework for more resilient banks and banking systems' and 'Basel III: International framework for liquidity risk measurement, standards and monitoring', released in December 2010 (BCBS, 2010).

\subsection{Relation between Capital Adequacy and Lending Spread Ratios}

We recognize the capital adequacy ratio (CAR) as the "cushion to guard a bank against the credit risk, operational risk and market risk” (Mahajan et al, 2012, p. 29). It is a key indicator of a bank's solvency and resilience (Avramova and Leslé, 2012). While, the lending spread ratio (LSR) is "the difference between the interest rate charged on loans and the rate paid on deposits" (Brock \& Suarezr, 2000, p.114). A plethora of research highlights the importance of relationship between capital adequacy ratios and LSR (Table 1). Parcon et al (2012) argue that an increase in lending rates, as a strategy to meet the new capital requirements may have a negative impact on the economy. In some countries, it was found that the implementation of higher CAR impacts positively on LSR (Wong, 2010; Di Biase, 2012), while in other countries the higher CAR has a neutral impact on LSR as a result of Basel III implementation.

\section{Table 1 - Sample of the Literature Review on the Relationship between CAR-LSR}

\begin{tabular}{|l|l|l|}
\hline $\begin{array}{l}\text { Authors - Country } \\
\text { of Context }\end{array}$ & Finding & $\begin{array}{l}\Delta \text { LSR } \\
(\%)\end{array}$ \\
\hline $\begin{array}{l}\text { Wong (2010) - } \\
\text { Thailand }\end{array}$ & $\begin{array}{l}\text { To cover the } 1 \% \text { increase in capital adequacy ratios, the LSR needs } \\
\text { to increase by 0.83\% }\end{array}$ & +0.83 \\
\hline $\begin{array}{l}\text { Cosimano and } \\
\text { Hakura, (2011) - } \\
\text { United States, Japan, } \\
\text { and Denmark }\end{array}$ & $\begin{array}{l}\text { It has been found that the increase in } \text { equity- to asset ratio by } 1.3 \\
\text { percentage points leads lending ratio to increase by } 16 \text { basis }\end{array}$ & +0.16 \\
\hline $\begin{array}{l}\text { Aiyar et al (2012) - } \\
\text { UK }\end{array}$ & $\begin{array}{l}\text { Recognized a negative impact of higher capital requirements on bank } \\
\text { lending in the UK. }\end{array}$ & \\
\hline $\begin{array}{l}\text { Elliott et al (2012) - } \\
\text { Japan } \\
\text { Europe, United States }\end{array}$ & $\begin{array}{l}\text { The findings revealed that the average lending rates might rise by: } 8 \\
\text { basis points in Japan (8bp), Europe (18bp), US (28bp) }\end{array}$ & +0.08 \\
\hline $\begin{array}{l}\text { Eita (2012) - Namibia } \\
\text { Ms the cost of funds for commercial banks increases, it may be } \\
\text { passed on to consumers by means of higher LSR. }\end{array}$ & +0.18 \\
\hline $\begin{array}{l}\text { Miles et al (2013) - } \\
\text { UK }\end{array}$ & $\begin{array}{l}\text { The researchers found that a 1pp (percentage point) increase in CAR } \\
\text { causes LSR to increase by 5.5 basis points in UK banks. }\end{array}$ & +0.28 \\
\hline $\begin{array}{l}\text { Santos and Winton } \\
\text { (2013) - United } \\
\text { Stated }\end{array}$ & $\begin{array}{l}\text { The authors find a moderate effect of bank capital on LSR for the } \\
\text { United States banks. }\end{array}$ & \\
\hline
\end{tabular}




\begin{tabular}{|l|l|l|}
\hline $\begin{array}{l}\text { Swamy and } \\
\text { Hyderabad (2014) - } \\
\text { India }\end{array}$ & $\begin{array}{l}\text { The results indicate that a 1pp increase in capital ratio can be } \\
\text { recovered by increasing LSR by 31 basis points }\end{array}$ & +0.31 \\
\hline $\begin{array}{l}\text { Corbae and D`erasmo } \\
(2014) \text { - US }\end{array}$ & $\begin{array}{l}\text { In respond to higher capital and liquidity requirements in the US that } \\
\text { lending rates increase by 50 basis points as a result of an increase in } \\
\text { CAR from 4\% to 6\%. }\end{array}$ & +0.25 \\
\hline $\begin{array}{l}\text { Maredza (2016) - } \\
\text { South Africa }\end{array}$ & $\begin{array}{l}1 \text { pp increase in the capital requirements leads on average to between } \\
12-14 \text { basis points increase in the cost of intermediation for the time } \\
\text { horizon of 12 years }(2001-2012) .\end{array}$ & +0.13 \\
\hline
\end{tabular}

Using an accounting-based model, King (2010) has estimated how much LSR would increase if banks are required to hold more capital. In order to mitigate the effect of this cost, banks have many alternatives to proceed: commercial banks may engage in different non-lending activities, these other activities may influence the pricing of loan products due to cross-subsidization of bank products (Hidayat et al, 2012). An open question is whether higher regulatory requirements will increase the LSR. Previous literature on capital regulation is mixed on whether Basel III capital requirements leads banking institutions to increase their LSR. Empirical models by Elliott (2010), Kashyap et al (2010), Swamy and Hyderabad (2014), among others, find that the impact of CAR on LSR is modest. Thus this study will investigate the impact of CAR on LSR in Lebanese commercial banks and the following sections will analyze the issue.

\section{Approach}

We explore the sensitivity of the potential impact of the implementation of Basel III capital requirements on LSR before, during and after the latest financial crisis in the commercial banks operated in Lebanon. To answer our research question, this study applies accounting based model on the data used to measure the higher cost associated with a $1 \%$ increase in CAR, and its impact on LSR. The significance of applying accounting based model resounds with the previous studies that assessed the impact of CAR on LSR. Our paper is applied to Lebanese commercial banks. The annual data of balance sheet and income statement are collected from Liban Bilan Banques, since this source is the most comprehensive publishing that includes a concise and trust data about Lebanese banking industry. After checking the quality of data included in the database, we eliminated a number of banks because of data availability necessary for the analysis for the period 2005-2016. Stylized facts on banks' balance sheets and income statement are provided in the appendix.

\section{Results and Discussion}

In order to distinguish the incremental effect of successive Basel regulation conditions, we conducted our analysis over three periods: (1) from 2005 to 2006; (2) from 2007 to 2010; and (3) from 2011 to 2016. We have included a set of tables showing the CAR - LSR relationship for each year from 2005 to 2016 for evidence. Our result demonstrates that CARs has a significant impact on LSR in 2009 through 2011, during crises periods, before turning to be insignificant at the end of 2012. The impact of CARs on LSR in the crises years (2009 and 2010) is relatively strong. This outcome resonates with Carlson et al (2013), who found that the relationship between CAR-LSR is strongly insignificant in the years prior to the recent crises (2005 and 2006) as well as at the beginning of the crisis (year 2007), after that it becomes significant in 2009 and 2010, before turning to be insignificant again in year 2011. On the other hand, the results are not consistent with the findings of Chun et al (2012), as they conclude that the LSR decreased between 2008 and 2010. They also suggest that the reason behind that is the significantly decreased ratio of RWA to total assets. Surprisingly, the latter relationship appears to be ineffective at the end of 2012 according to our study. Then, this relationship turned again to be effective in years 2013, 2014 and 2015. Since there are no previous literature studies that deal with addressing the impact of CARs on LSR year by year between 2012 and 2016, we cannot compare the results of these years with other studies findings. During the pre-crisis period, CAR reflects a notably higher ratios, while, in the crisis period, there is a deep shift as the CAR fell to an historic low ratio, after which is broadly returns to higher levels. To illustrate, Lebanese commercial banks experienced sharply decrease in CAR from $27.38 \%$ in 2006 to 
$15.10 \%$ in 2007; attributed to the 2006 war. As observed, most of Lebanese commercial banks haven't published its balance sheets at year 2007. Later, the banking system was able to overcome with strides this short-run hiccup. Commercial banks faced a decline in its Capital Adequacy Ratio during the recent financial crisis at years 2007 and 2008 (their average was $15.1 \%$ and $14.73 \%$ respectively). In 2009 and thereafter, these banks faced a positive growth on CAR. This increasing trend was a result of the implementation of Basel II and III capital requirements. In 2016, Lebanese commercial banks was highly capitalized with CAR reaching $20.58 \%$ as an average. This ratio indicates that commercial banks are well exceeding Basel III requirements and reflecting an adequate coverage of all types of risk (credit, market, and operational risk). Lending spread ratio also offer a mixed picture. Most of these spreads have been stable or narrower at the pre-crisis period. This spread has widened from around 3.179 basis points in early 2008 to around 14.38 basis points in 2010 . The timing of the movement of this indicator suggests that the recent crisis has played a substantial role: it widened sharply during the crisis, then narrowed somewhat thereafter to reach its lowest in late 2012. Then widened progressively in years after the crisis.

\section{Conclusion}

This research is an attempt to provide the Lebanese commercial banks a basic understanding of the impact of CAR-LSR on financial performance to help in formulating their future policies to mitigate the negative effects of the implementation of Basel III. LSR would require more risk to be absorbed by banks $0-14 \%$. Furthermore, this paper gives conceptual and empirical evidence to assertions in the commercial banks.

Previous studies that have inspected the consequences of the implementation of CARs have done so at various types of banks. It is essential to note that it is the first study in Lebanon that addresses this proposition. The finding of this study is consistent with the findings of the other studies as shown in table 2.

Table 2 - Effect of one percentage-point increase in CAR on LSR

\begin{tabular}{|l|c|l|}
\hline Country (ies) of Study & $\begin{array}{l}\text { Change in Lending Spread } \\
\text { (Basis points) }\end{array}$ & Reference \\
\hline Euro Area and United States & 60 to 65 & Roger and Vlček (2011) \\
\hline India & 31 & Swamy and Hyderabad (2014) \\
\hline Europe & 18.8 & Š́́TOROVÁ and TEPLÝ (2013) \\
\hline Japan, Europe, and USA & 5 to 15 & Elliott et al (2012) \\
\hline USA, Japan and Euro Area & 14.4 & Slovik and Cournède (2011) \\
\hline South Africa & 12 to 14 & Maredza (2016) \\
\hline Lebanon & $\mathbf{0 ~ t o ~} \mathbf{1 4}$ & Our research result \\
\hline 13 OECD countries & 13 & BCBS (2010a) \\
\hline United States and Japan & 12 & Cosimano and Hakura (2011) \\
\hline United Kingdom & 5.5 & Miles et al (2013) \\
\hline United States & 2.5 to 4.5 & Kashyap et al. (2010) \\
\hline
\end{tabular}

A closer look at figure 1 shows a clear contrast between the pre-crisis period, the crisis period, and then after. 
Trends in CAR and LSR, 2005-2016

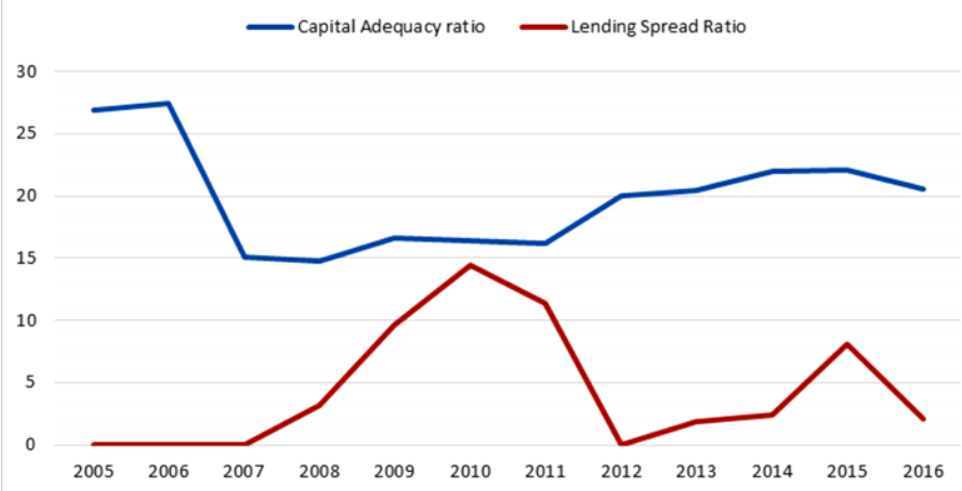

\begin{tabular}{|c|c|c|c|c|c|c|c|c|c|c|c|c|}
\hline CAR & 26.91 & 27.38 & 15.10 & 14.73 & 16.60 & 16.41 & 16.19 & 19.97 & 20.44 & 21.96 & 22.03 & 20.58 \\
\hline LSR & 0 & 0 & 0 & 3.179 & 9.59 & 14.38 & 11.39 & 0 & 1.87 & 2.37 & 8.07 & 2.11 \\
\hline N & 41 & 41 & 33 & 39 & 39 & 40 & 38 & 39 & 39 & $\mathbf{3 7}$ & $\mathbf{3 6}$ & $\mathbf{3 6}$ \\
\hline
\end{tabular}

Figure 1: The average of CAR, LSR in Lebanese commercial banks, 2005 2016 - Source: developed by author from Bilan Banques.

Finally, this paper considers the years between 2005 and 2016 by analyzing the data year by year in which they differ in the level of CARs and its dispersion to address the latter impact; taking into consideration that the higher capital requirement imposed under Basel III are fully implemented in Lebanese commercial banks. Accordingly, our findings are based on realistic data and not on assumptions.

Table 3 - Changes in LSR, 2005 - 2016

\begin{tabular}{|c|c|c|c|}
\hline Year & N & Basel & $\begin{array}{l}\text { Impact of changing CAR by 1pp on } \\
\text { LSR? }\end{array}$ \\
\hline $\mathbf{2 0 0 5}$ & 41 & I & None \\
\hline $\mathbf{2 0 0 6}$ & 41 & I & None \\
\hline $\mathbf{2 0 0 7}$ & 33 & II & 3.179 basis points $(0.0317 \%)$ \\
\hline 2008 & 39 & II & 9.59 basis points $(0.0959 \%)$ \\
\hline 2009 & 39 & II & 14.38 basis points $(0.1438 \%)$ \\
\hline 2010 & 40 & II & 11.39 basis points $(0.113 \%)$ \\
\hline 2011 & 38 & III & 1.87 basis points $(0.0187 \%)$ \\
\hline $\mathbf{2 0 1 2}$ & 39 & III & 2.37 basis points $(0.02377 \%)$ \\
\hline 2013 & 39 & III & 8.07 basis points $(0.0807 \%)$ \\
\hline $\mathbf{2 0 1 4}$ & 37 & III & 2.91 basis points $(0.0291 \%)$ \\
\hline 2015 & 36 & III & \\
\hline 2016 & 36 & III & \\
\hline
\end{tabular}

As shown, there is an evidence that CAR impact LSR at years 2008, 2009, 2010, 2011, 2013, 2014, 2015 and 2016. The magnitude of this impact is smaller and modest in general. Accordingly, King's model is not supported in pre-crisis period $(2005,2006,2007)$, and in year 2012. The magnitude of our estimates in comparison with the results of the previous studies seems to be modest in 2009, 2010, 2011 and 2015. The findings are in line with the earlier studies that found for every one percentage point increase in CAR; LSR must increase by 15 basis points (King, 2010). The estimation of the current study suggests that a 
one percentage point increase in CAR leads to a lower impact on LSR as on years 2008, 2013, 2014 and 2016. What happened in years 2008 and 2013 to change the previous quo? This question is a direction for future research.

\section{Research Limitations}

Our approach has several limitations. First, the focus was on the debate of how CAR affects LSR. However, when I examine the latter relationship, I ignore the role of other alternative choices faced by banks, which might be taken into consideration such as the decrease in Return on Equity (ROE), Risk weighted assets (RWA), operating expense ratio, and increase in non-interest income ratio. Second, the sample was not large enough because the availability of data for commercial banks is restricted to 33 out of 53 at the end of 2007, while on the remainder years; the sample was in between 38 to 41 out of 53 Lebanese commercial banks. Therefore, a considerable sample bias may exist due to the small sample size. Third, while the new proposal under Basel III implies changes both in capital and liquidity requirements, this study focuses exclusively on the effects of the higher capital requirements. Though, the new liquidity requirements may also have some cost implications, such as lower interest income (since banks are required to hold more liquid and less risky assets) and higher interest expenses (associated with debt maturity extension). It has been completely ignored from the scope of the present study. Finally, a noticeable limitation is presented as an additional investigation is obviously needed in the incorporation of investment banks and other non-bank financial sector as the analysis and the outcomes of this paper are based on one sector of the banking industry.

\section{References}

Aiyar, S., Calomiris, C.W. and Wieladek, T., 2012. Does macro-pru leak? Evidence from a UK policy experiment (No. w17822). National Bureau of Economic Research.

Athanasoglou, P. P., Brissimis, S. N., \& Delis, M. D. (2008). Bank-Specific, Industry-Specific and Macroeconomic Determinants of Bank Profitability. Journal of International Financial Markets, Institutions and Money, 18(2), 121-136.

Avramova, M.S. and Le Leslé, V., 2012. Revisiting Risk-Weighted Assets (No. 12-90). International Monetary Fund.

Berger, A.N., Herring, R. J. \& Szego, G. P. (1995). The role of capital in financial institutions. Journal of Banking and Finance, 19 (3-4), 393- 430.

Bilal, Z. O., \& Salim, B. F. (2016). Does Basil III Implementation Impact on Financial Performance? Evidence from Omani's Commercial Banks. International Journal of Economics and Financial Issues, 6(3).

Brock, P.L. and Suarez, L.R., 2000. Understanding the behavior of bank spreads in Latin America. Journal of development Economics 63, 113-134.

Brownbridge, M. (2015). How relevant are the Basel capital reforms for sub-Saharan Africa? Journal of Risk Management in Financial Institutions, 8(2), 153-162.

Carlson, M., Shan, H. and Warusawitharana, M., 2013. Capital ratios and bank lending: A matched bank approach. Journal of Financial Intermediation 22, 663-687.

Chun, S.E., Kim, H. and Ko, W., 2012. The Impact of Strengthened Basel III Banking Regulation on Lending Spreads: Comparisons across Countries and Business Models (No. 2012-15). BOK Working paper.

Corbae, D. and D'Erasmo, P., 2014. Capital requirements in a quantitative model of banking industry dynamics.

Cornett, M.M., McNutt, J.J., Strahan, P.E. and Tehranian, H., 2011. Liquidity risk management and credit supply in the financial crisis. Journal of Financial Economics 101, 297-312.

Cosimano, T.F. and Hakura, D.S., 2011. Bank Behavior in Response to Basel III: A Cross-Country Analysis. International Monetary Fund.

Curry, T., Feldman, R., \& Johnson, J. (2012). "Regulatory capital Rules: Regulatory Capital, Implementation of Basel III, Minimum Regulatory Capital Ratios, Capital Adequacy, Transition Provisions, and Prompt Corrective Action", Federal Register. 
Dermine, J. (2014). Basel III Leverage Ratio Requirement and the Probability of Bank Runs. Journal of Banking \& Finance.

Di Biase, P., 2012. The Impact of Basel III on Italian Banks' Loan Rates: An Accounting-Based Approach. The International Business \& Economics Research Journal (Online), 11, 1269-1280.

Eita, J.H., 2012. Explaining interest rate spread in Namibia. The International Business \& Economics Research Journal (Online) 11, 1123.

Elliott, D.J., 2010. A further exploration of bank capital requirements: effects of competition from other financial sectors and effects of size of bank or borrower and of loan type. Brookings Institution.

Elliott, D., Salloy, S., \& Santos, A. O., 2012. Assessing the cost of financial regulation, IMF Working Paper, WP/12/233.

Gambacorta, L. and Marques-Ibanez, D., 2011. The bank lending channel: lessons from the crisis. Economic Policy 26, 135-182.

Hidayat, W.Y., Kakinaka, M. and Miyamoto, H., 2012. Bank risk and non-interest income activities in the Indonesian banking industry. Journal of Asian Economics 23, 335-343.

Huang, Z., \& Pan, H. (2016). A Study on the Impact of Capital Structure of China's Listed Commercial Banks on Profitability. Management \& Engineering, (22), 65.

Karim, M. A., Hassan, M. K., Hassan, T., \& Mohamad, S. (2014). Capital adequacy and lending and deposit behaviors of conventional and Islamic banks. Pacific-Basin Finance Journal, 28, 58-75. Doi:10.1016/j.pacfin.2013.11.002

Kashyap, A.K., Stein, J.C. and Hanson, S., 2010. An analysis of the impact of 'substantially heightened 'capital requirements on large financial institutions. Booth School of Business, University of Chicago, mimeo, 2.

King, M. R., 2010. Mapping Capital and Liquidity Requirements to Bank Lending spread. BIS Working Paper No. 324.

Krishnan, S.V. \& Sukar, A. (2014). Capital Ratios of US Banks. International Journal of Business \& Economics Perspectives, 9 (1), 135-149.

Mahajan, P., Bhatia, A., \& Chander, S., 2012. ROA Performance of Public Sector Banks in India. IUP Journal of Bank Management 119, 22-35.

Maredza, A., 2016. Do capital requirements affect cost of intermediation? Evidence from a panel of South African banks. The Journal of Developing Areas 50, 35-51.

Miles, D., Yang, J., Marcheggiano, G., 2013. Optimal Bank Capital. The Economic Journal 123, 1-37.

Naimy V. (2011). Failure Prediction With Logit and Bank-Level Fundamentals Models Applied on the Lebanese Commercial Banks. The Journal of American Academy of Business, Cambridge, 16(3), 189-196.

Parcon-Santos, H.C. and Bernabe Jr, E.M., 2012. The Macroeconomic Effects of Basel III Implementation in the Philippines: A Preliminary Assessment.

Peek, J. \& Rosengren, E. (1995). The Capital Crunch: Neither a Borrower or a Lender Be. Journal of Money, Credit and Banking, 27(3), 625-638.

Reda, I. A., Rjoub, H. \& Alrub, A. A.(2016). The Determinants of Banks' Profitability under Basel Regulations: Evidence from Lebanon. International Journal of Economics and Finance, 8(10).

Roger, S. and Vlček, J., 2011. Macroeconomic costs of higher bank capital and liquidity requirements.

Santos, J., \& Winton, A. (2013). "Bank Capital, Borrower Power, and Loan Rates." Working Paper. Available at SSRN: http://ssrn.com/abstract $=1343897$

Slovik, P., \& Cournede, B., 2011. Macroeconomic impact of Basel III. OECD Economics Department Working Papers, p. 844.

Šutorova, B., \& Teply, P. (2013). The Impact of Basel III on Lending Rates of EU Banks. Finance a úvěrCzech. Journal of Economics and Finance, 63 (3), 226-243.

Swamy, V., \& Hyderabad. 2014. Modelling the Impact of New Capital Regulations on Bank Profitability. MPRA Munich Personal RePEc Archive, Available at SSRN 2491397. Access date at October 24, 2016.

Wong, M.C.S., 2010. The New Basel liquidity requirements: Implications and impacts. Journal of Risk and Regulation North Asia 2, 261-266. 


\section{Appendix}

Table A-1 shows the balance sheet and income statement for representative banks for each year. All items are shown as a percentage of total assets to allow comparability in the pre-crisis period, during and after the crisis. It reveals considerable differences in assets and liabilities over the period of the study. These variances are significant for explaining the variation in the impact of CAR on LSR. In order to analyze the ratios of Net Income, Return on Equity, and other ratios, we use the formulas in table A-2.

The constituents of income statement items are also exhibited in table A-1 with the following variable considered:

- Net interest income represents the difference between interest income and interest expense. Total non-interest income is the sum of trading income and non-interest income excluding trading.

- Revenues represent the sum of net interest income and non-interest income.

- Operating expense represents the sum of personnel expense and other administrative expense.

- Net Income (NI) is accounted as operating profit less taxes; while, Return on Equity (ROE) represents Net Income (NI) divided by Equity.

Table A-1 - Balance Sheet and Income Statement Data for Representative Sample

\begin{tabular}{|c|c|c|c|c|c|c|c|c|c|c|c|c|}
\hline Items & 2005 & 2006 & 2007 & 2008 & 2009 & 2010 & 2011 & 2012 & 2013 & 2014 & 2015 & 2016 \\
\hline \multicolumn{13}{|l|}{ Balance } \\
\hline Assets & 28.0 & 23.3 & 22.3 & 23.5 & 24.8 & 24.4 & 16.5 & 18.7 & 18.8 & 19.1 & 19.5 & 22.20 \\
\hline Cash & 7 & 6 & 6 & 8 & 9 & 9 & 0 & 3 & & 6 & & 11.27 \\
\hline balances & 16.6 & 19.4 & 23.1 & 18.5 & 17.0 & 16.8 & 15.3 & 14.3 & 13.8 & 13.4 & 11.6 & 2.11 \\
\hline Interbank & 6 & 5 & 8 & 3 & 1 & 5 & 8 & 6 & 1 & 6 & 6 & 31.34 \\
\hline claims & 2.73 & 2.31 & 2.39 & 2.08 & 1.65 & 2.35 & 1.98 & 1.74 & 1.91 & 2.16 & 2.70 & 29.90 \\
\hline Trading & 23.6 & 24.5 & 25.3 & 26.1 & 26.0 & 27.9 & 28.8 & 29.9 & 30.5 & 31.0 & 32.0 & 3.20 \\
\hline related assets & 5 & 3 & 7 & 2 & 1 & 0 & 8 & 4 & 5 & 3 & 2 & 100 \\
\hline Net loans, & 24.8 & 26.5 & 23.2 & 26.0 & 27.2 & 25.2 & 33.9 & 31.7 & 31.8 & 31.1 & 31.2 & \\
\hline leases & 7 & 7 & 1 & 1 & 2 & 6 & 7 & 6 & 4 & 9 & 2 & \\
\hline Investments & 4.03 & 3.78 & 3.49 & 3.68 & 3.23 & 3.18 & 3.29 & 3.47 & 3.08 & 2.99 & 2.90 & 73.65 \\
\hline and & 100 & 100 & 100 & 100 & 100 & 100 & 100 & 100 & 100 & 100 & 100 & 8.16 \\
\hline securities & & & & & & & & & & & & 0.08 \\
\hline Other assets & & & & & & & & & & & & 2.07 \\
\hline Total & & 78.6 & 77.8 & 79.5 & 77.5 & 77.7 & 76.7 & 76.0 & 76.3 & 75.6 & 75.1 & 2.71 \\
\hline & 78.8 & 8 & 1 & 6 & 3 & 1 & 5 & 7 & 2 & 5 & 1 & 86.66 \\
\hline Liabilities & 5 & 6.71 & 7.52 & 6.43 & 6.92 & 7.23 & 7.12 & 7.12 & 7.86 & 7.85 & 7.41 & 13.34 \\
\hline and Equity & 6.44 & 0.69 & 0.31 & 0.26 & 0.27 & 0.22 & 0.26 & 0.08 & 0.06 & 0.03 & 0.01 & 100 \\
\hline Deposits & 0.88 & 0.88 & 1.02 & 0.73 & 1.11 & 1.33 & 1.59 & 1.71 & 1.73 & 1.91 & 2.07 & \\
\hline Interbank & 0.89 & 2.32 & 2.38 & 2.30 & 2.02 & 1.86 & 1.39 & 1.52 & 1.47 & 1.19 & 1.43 & \\
\hline funding & 2.63 & 89.2 & 89.0 & 89.0 & 87.8 & 88.3 & 88.1 & 86.5 & 87.4 & 86.6 & 86.0 & 4.82 \\
\hline Trading & 89.6 & 8 & 4 & 4 & 4 & 5 & 1 & 0 & 2 & 2 & 4 & 2.97 \\
\hline related & 8 & 10.7 & 10.9 & 10.7 & 12.1 & 11.6 & 11.8 & 13.5 & 12.5 & 13.3 & 13.9 & 1.85 \\
\hline liabilities & 10.3 & 2 & 5 & 3 & 6 & 5 & 9 & 0 & 8 & 8 & 6 & 0.91 \\
\hline Wholesale & 2 & 100 & 100 & 100 & 100 & 100 & 100 & 100 & 100 & 100 & 100 & 2.76 \\
\hline funding & 100 & & & & & & & & & & & 1.88 \\
\hline Other & & & & & & & & & & & & 0.13 \\
\hline liabilities & 5.85 & 6.44 & 6.24 & 5.66 & 5.23 & 5.13 & 4.89 & 4.80 & 4.85 & 4.87 & 4.91 & 0.74 \\
\hline Total & 3.90 & 4.41 & 4.18 & 3.41 & 3.22 & 3.00 & 2.94 & 3.00 & 3.01 & 3.09 & 3.19 & 5.54 \\
\hline liabilities & 1.96 & 2.03 & 2.06 & 2.25 & 2.01 & 2.12 & 1.95 & 1.80 & 1.84 & 1.78 & 1.72 & 11.04 \\
\hline
\end{tabular}

Comment [ZM1]: This table needs to be formatted as values does not correspond to items. 


\begin{tabular}{|c|c|c|c|c|c|c|c|c|c|c|c|c|}
\hline Shareholders & 0.90 & 0.90 & 1.03 & 0.85 & 1.00 & 1.05 & 1.02 & 0.91 & 0.90 & 0.95 & 1.02 & $\mathrm{X}$ \\
\hline , equity & 2.86 & 2.94 & 3.09 & 3.10 & 3.01 & 3.18 & 2.97 & 2.71 & 2.73 & 2.73 & 2.74 & \\
\hline Total & 1.99 & 1.99 & 1.89 & 1.84 & 1.82 & 1.82 & 1.78 & 2.14 & 1.91 & 1.73 & 1.70 & \\
\hline & 0.13 & 0.14 & 0.18 & 0.19 & 0.18 & 0.20 & 0.18 & 0.09 & 0.12 & 0.15 & 0.14 & \\
\hline Income & 0.74 & 0.80 & 1.02 & 1.06 & 1.01 & 1.15 & 1.01 & 0.48 & 0.70 & 0.84 & 0.91 & \\
\hline statement & 7.14 & 7.48 & 9.31 & 9.91 & 8.29 & 9.91 & 8.51 & 3.57 & 5.60 & 6.29 & 8.39 & \\
\hline Interest & 15.6 & 11.3 & 11.8 & 11.2 & 11.0 & $9.7 x$ & 15.1 & 13.3 & 12.7 & 12.3 & 11.5 & \\
\hline income & $\mathrm{X}$ & $\mathrm{X}$ & $\mathrm{X}$ & $\mathrm{X}$ & $\mathrm{x}$ & & $\mathrm{x}$ & $\mathrm{x}$ & $\mathrm{x}$ & $\mathrm{x}$ & $\mathrm{X}$ & \\
\hline (-) Interest & & & & & & & & & & & & \\
\hline $\begin{array}{l}\text { expense } \\
(=) \quad \text { Net }\end{array}$ & & & & & & & & & & & & \\
\hline interest & & & & & & & & & & & & \\
\hline income & & & & & & & & & & & & \\
\hline Non- & & & & & & & & & & & & \\
\hline interest & & & & & & & & & & & & \\
\hline $\begin{array}{l}\text { income } \\
(=) \text { Revenue }\end{array}$ & & & & & & & & & & & & \\
\hline (-) Operating & & & & & & & & & & & & \\
\hline expenses & & & & & & & & & & & & \\
\hline (-) Taxes & & & & & & & & & & & & \\
\hline$(=)$ & & & & & & & & & & & & \\
\hline Income & & & & & & & & & & & & \\
\hline Return & & & & & & & & & & & & \\
\hline Equity & & & & & & & & & & & & \\
\hline Leverage & & & & & & & & & & & & \\
\hline multiple & & & & & & & & & & & & \\
\hline
\end{tabular}

Table A-2 - Formulas using in Applying Accounting - Based Model

\begin{tabular}{|c|c|}
\hline Variable & Formula \\
\hline Net Income (NI) & $\begin{array}{c}N I=[(\text { IncomeLoans }+ \text { OtherIntIncome }- \text { Intexp })+\text { NonIntInc } \\
- \text { OpExp }] .(1-\operatorname{tax})\end{array}$ \\
\hline $\begin{array}{l}\text { Return on Equity } \\
\text { (ROE) }\end{array}$ & $\overline{R O E}=\frac{\text { Net Income }}{\text { Equity }}$ \\
\hline $\begin{array}{l}\text { Change in interest expense } \\
(\Delta \text { Intexp) }\end{array}$ & $\begin{array}{l}\Delta \text { Intexp } \\
=\frac{\text { Intexp }-(0.01 * \text { short term debt })-(0.02 * \text { long term debt })}{\text { Deposits }+ \text { short term debt }+ \text { long term debt }}\end{array}$ \\
\hline $\begin{array}{l}\text { New wholesale funding } \\
\left(W F_{t+1}\right)\end{array}$ & $W F_{t+1}=W F_{t}-\Delta$ TotalCapitalRatio.$R W A_{t+1}$ \\
\hline $\begin{array}{l}\text { New Shareholders' Equity } \\
\left(E_{t+1}\right)\end{array}$ & $E_{t+1}=E_{t}+\Delta$ TotalCapitalRatio $\cdot R W A_{t+1}$ \\
\hline Net Income $\left(N I_{t+1}\right)$ & $N I_{t+1}=R O E \cdot E_{t+1}$ \\
\hline Pretax Income $\left(P T I_{t+1}\right)$ & $P T I_{t+1}=\frac{N I_{t+1}}{1-\operatorname{tax}}$ \\
\hline Revenue $\left(R V_{t+1}\right)$ & $R V_{t+1}=O p E x p+P T I_{t+1}$ \\
\hline Net Interest Income $\left(N I I_{t+1}\right)$ & $N I I_{t+1}=R V_{t+1}-$ NonIntInc \\
\hline Interest Income $\left(I I_{t+1}\right)$ & $I I_{t+1}=N I I_{t+1}+O p E x p_{t+1}$ \\
\hline $\begin{array}{l}\text { Change in lending spread ratio } \\
(\Delta \mathrm{LSR})\end{array}$ & $\Delta \mathrm{LSR}=\frac{\text { the additional increase in pretax income }}{\text { Net Loans }}$ \\
\hline $\begin{array}{l}\text { The additional increase in } \\
\text { pretax income }\end{array}$ & $\begin{array}{l}\qquad P T I_{t+1}-\left(P T I_{t}+\text { Intexp }\right) \\
P T I_{t} \text { Represents the initial pretax income, and } \Delta \text { Intexp represents the } \\
\text { change in pretax income. }\end{array}$ \\
\hline
\end{tabular}


Table A-2005 - The impact of CAR on LSR in the pre-crisis period, years 2005

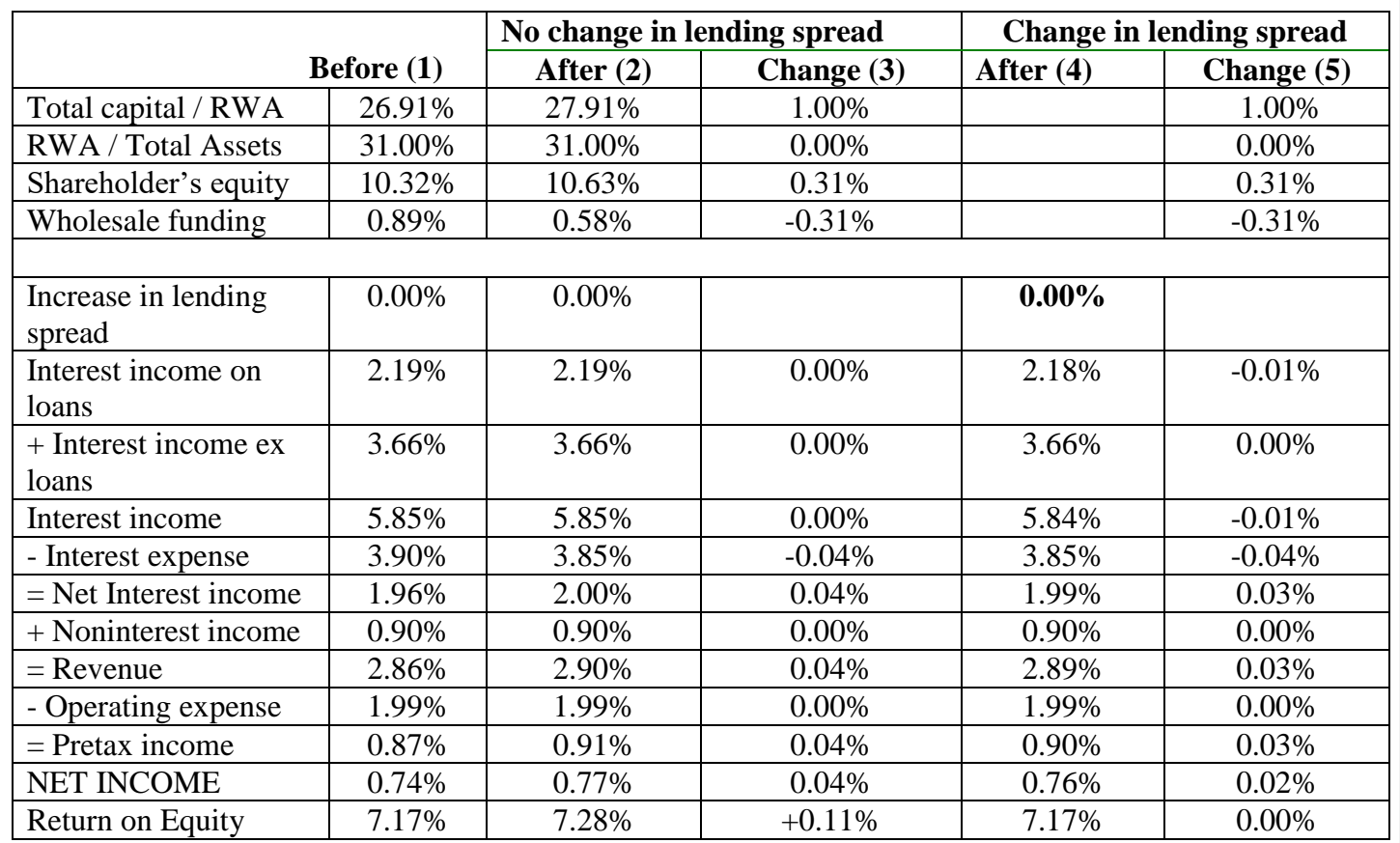

Table A-2006 - Impact of CARs on LSR among 41 Representative Banks, year-end 2006

\begin{tabular}{|l|c|c|c|c|c|}
\hline \multicolumn{2}{|}{ Before (1) } & \multicolumn{2}{c|}{ No change in lending spread } & \multicolumn{2}{c|}{ Change in lending spread } \\
\cline { 3 - 6 } & After (2) & Change (3) & After (4) & Change (5) \\
\hline Total capital / RWA & $27.37 \%$ & $28.37 \%$ & $1.00 \%$ & & $1.00 \%$ \\
\hline RWA / Total Assets & $32.74 \%$ & $32.74 \%$ & $0.00 \%$ & & $0.00 \%$ \\
\hline Shareholder's equity & $10.72 \%$ & $11.05 \%$ & $0.33 \%$ & & $0.33 \%$ \\
\hline Wholesale funding & $0.88 \%$ & $0.55 \%$ & $-0.33 \%$ & & $-0.33 \%$ \\
\hline & & & & & \\
\hline $\begin{array}{l}\text { Increase in lending } \\
\text { spread }\end{array}$ & $0.00 \%$ & $0.00 \%$ & & & \\
\hline $\begin{array}{l}\text { Interest income on } \\
\text { loans }\end{array}$ & $2.24 \%$ & $2.24 \%$ & $0.00 \%$ & \\
\hline $\begin{array}{l}\text { + Interest income ex } \\
\text { loans }\end{array}$ & $4.20 \%$ & $4.20 \%$ & $0.00 \%$ & $4.20 \%$ & $0.00 \%$ \\
\hline Interest income & $6.44 \%$ & $6.44 \%$ & $0.00 \%$ & $6.42 \%$ & $0.02 \%$ \\
\hline - Interest expense & $4.41 \%$ & $4.36 \%$ & $-0.05 \%$ & $4.36 \%$ & $-0.05 \%$ \\
\hline = Net Interest income & $2.03 \%$ & $2.08 \%$ & $0.05 \%$ & $2.06 \%$ & $0.03 \%$ \\
\hline + Noninterest income & $0.90 \%$ & $0.90 \%$ & $0.00 \%$ & $0.90 \%$ & $0.00 \%$ \\
\hline = Revenue & $2.94 \%$ & $2.99 \%$ & $0.05 \%$ & $2.96 \%$ & $0.02 \%$ \\
\hline - Operating expense & $1.99 \%$ & $1.99 \%$ & $0.00 \%$ & $1.99 \%$ & $0.00 \%$ \\
\hline = Pretax income & $0.94 \%$ & $1.00 \%$ & $0.06 \%$ & $0.97 \%$ & $0.03 \%$ \\
\hline NET INCOME & $0.80 \%$ & $0.85 \%$ & $0.05 \%$ & $0.83 \%$ & $0.02 \%$ \\
\hline Return on equity & $7.48 \%$ & $7.66 \%$ & $+0.18 \%$ & $7.48 \%$ & $0.00 \%$ \\
\hline
\end{tabular}


Table A-2007 - Impact of CARs on LSR among 33 Representative Banks, yearend 2007

\begin{tabular}{|c|c|c|c|c|c|}
\hline \multirow{2}{*}{\multicolumn{2}{|c|}{ Before (1) }} & \multicolumn{2}{|c|}{ No change in lending spread } & \multicolumn{2}{|c|}{ Change in lending spread } \\
\hline & & After (2) & Change (3) & After (4) & Change (5) \\
\hline Total capital / RWA & $15.10 \%$ & $16.10 \%$ & $1.00 \%$ & & $1.00 \%$ \\
\hline RWA / Total Assets & $32.60 \%$ & $32.60 \%$ & $0.00 \%$ & & $0.00 \%$ \\
\hline Shareholder's equity & $10.95 \%$ & $11.28 \%$ & $0.33 \%$ & & $0.33 \%$ \\
\hline Wholesale funding & $1.02 \%$ & $0.69 \%$ & $-0.33 \%$ & & $-0.33 \%$ \\
\hline $\begin{array}{l}\text { Increase in lending } \\
\text { spread }\end{array}$ & $0.00 \%$ & $0.00 \%$ & & $0.00 \%$ & \\
\hline $\begin{array}{l}\text { Interest income on } \\
\text { loans }\end{array}$ & $2.16 \%$ & $2.16 \%$ & $0.00 \%$ & $2.16 \%$ & $0.00 \%$ \\
\hline $\begin{array}{l}+ \text { Interest income ex } \\
\text { loans }\end{array}$ & $4.08 \%$ & $4.08 \%$ & $0.00 \%$ & $4.08 \%$ & $0.00 \%$ \\
\hline Interest income & $6.24 \%$ & $6.24 \%$ & $0.00 \%$ & $6.24 \%$ & $0.00 \%$ \\
\hline - Interest expense & $4.18 \%$ & $4.14 \%$ & $-0.04 \%$ & $4.14 \%$ & $-0.04 \%$ \\
\hline$=$ Net Interest income & $2.06 \%$ & $2.10 \%$ & $0.04 \%$ & $2.09 \%$ & $0.03 \%$ \\
\hline + Noninterest income & $1.03 \%$ & $1.03 \%$ & $0.00 \%$ & $1.03 \%$ & $0.00 \%$ \\
\hline$=$ Revenue & $3.09 \%$ & $3.13 \%$ & $0.04 \%$ & $3.12 \%$ & $0.03 \%$ \\
\hline - Operating expense & $1.89 \%$ & $1.89 \%$ & $0.00 \%$ & $1.89 \%$ & $0.00 \%$ \\
\hline$=$ Pretax income & $1.20 \%$ & $1.24 \%$ & $0.04 \%$ & $1.24 \%$ & $0.01 \%$ \\
\hline NET INCOME & $1.02 \%$ & $1.06 \%$ & $0.04 \%$ & $1.05 \%$ & $0.01 \%$ \\
\hline Return on equity & $9.32 \%$ & $9.36 \%$ & $+0.05 \%$ & $9.32 \%$ & $0.00 \%$ \\
\hline
\end{tabular}

Table A- 2008 - Impact of CARs on LSR among 39 Representative Banks, yearend 2008

\begin{tabular}{|l|c|c|c|c|c|}
\hline & & \multicolumn{2}{c|}{ No change in lending spread } & \multicolumn{2}{c|}{ Change in lending spread } \\
\cline { 3 - 6 } & Before (1) & After (2) & Change (3) & After (4) & Change (5) \\
\hline Total capital / RWA & $14.73 \%$ & $15.73 \%$ & $1.00 \%$ & & $1.00 \%$ \\
\hline RWA / Total Assets & $32.84 \%$ & $32.84 \%$ & $0.00 \%$ & & $0.00 \%$ \\
\hline Shareholder's equity & $10.73 \%$ & $11.05 \%$ & $0.33 \%$ & & $0.33 \%$ \\
\hline Wholesale funding & $0.73 \%$ & $0.40 \%$ & $-0.33 \%$ & & $-0.33 \%$ \\
\hline & & & & & \\
\hline $\begin{array}{l}\text { Increase in lending } \\
\text { spread }\end{array}$ & $0.00 \%$ & $0.00 \%$ & & & \\
\hline $\begin{array}{l}\text { Interest income on } \\
\text { loans }\end{array}$ & $1.96 \%$ & $1.96 \%$ & $0.03 \%$ & \\
\hline $\begin{array}{l}\text { + Interest income ex } \\
\text { loans }\end{array}$ & $3.70 \%$ & $3.70 \%$ & $0.00 \%$ & $3.70 \%$ & $0.00 \%$ \\
\hline Interest income & $5.66 \%$ & $5.66 \%$ & $0.00 \%$ & $5.67 \%$ & $0.01 \%$ \\
\hline - Interest expense & $3.41 \%$ & $3.38 \%$ & $-0.03 \%$ & $3.38 \%$ & $-0.03 \%$ \\
\hline = Net Interest income & $2.25 \%$ & $2.28 \%$ & $0.03 \%$ & $2.29 \%$ & $0.04 \%$ \\
\hline + Noninterest income & $0.85 \%$ & $0.85 \%$ & $0.00 \%$ & $0.85 \%$ & $0.00 \%$ \\
\hline = Revenue & $3.10 \%$ & $3.12 \%$ & $0.02 \%$ & $3.13 \%$ & $0.04 \%$ \\
\hline - Operating expense & $1.84 \%$ & $1.84 \%$ & $0.00 \%$ & $1.84 \%$ & $0.00 \%$ \\
\hline = Pretax income & $1.25 \%$ & $1.28 \%$ & $0.03 \%$ & $1.29 \%$ & $0.04 \%$ \\
\hline NET INCOME & $1.06 \%$ & $1.09 \%$ & $0.03 \%$ & $1.10 \%$ & $0.04 \%$ \\
\hline Return on equity & $9.91 \%$ & $9.85 \%$ & $-0.06 \%$ & $9.91 \%$ & $0.00 \%$ \\
\hline
\end{tabular}


Table A - 2009 - Impact of CARs on LSR among 39 Representative Banks, year - end 2009

\begin{tabular}{|c|c|c|c|c|c|}
\hline & \multirow[b]{2}{*}{ Before (1) } & \multicolumn{2}{|c|}{ No change in lending spread } & \multicolumn{2}{|c|}{ Change in lending spread } \\
\hline & & After (2) & Change (3) & After (4) & Change (5) \\
\hline Total capital / RWA & $16.60 \%$ & $17.60 \%$ & $1.00 \%$ & & $1.00 \%$ \\
\hline RWA / Total Assets & $62.22 \%$ & $62.22 \%$ & $0.00 \%$ & & $0.00 \%$ \\
\hline Shareholder's equity & $12.16 \%$ & $12.78 \%$ & $0.62 \%$ & & $0.62 \%$ \\
\hline Wholesale funding & $1.11 \%$ & $0.49 \%$ & $-0.62 \%$ & & $-0.62 \%$ \\
\hline $\begin{array}{l}\text { Increase in lending } \\
\text { spread }\end{array}$ & $0.00 \%$ & $0.00 \%$ & & $0.09 \%$ & \\
\hline $\begin{array}{l}\text { Interest income on } \\
\text { loans }\end{array}$ & $1.82 \%$ & $1.82 \%$ & $0.00 \%$ & $1.85 \%$ & $0.03 \%$ \\
\hline $\begin{array}{l}+ \text { Interest income ex } \\
\text { loans }\end{array}$ & $3.41 \%$ & $3.41 \%$ & $0.00 \%$ & $3.41 \%$ & $0.00 \%$ \\
\hline Interest income & $5.23 \%$ & $5.23 \%$ & $0.00 \%$ & $5.26 \%$ & $0.03 \%$ \\
\hline - Interest expense & $3.22 \%$ & $3.18 \%$ & $-0.04 \%$ & $3.18 \%$ & $-0.04 \%$ \\
\hline$=$ Net Interest income & $2.01 \%$ & $2.05 \%$ & $0.04 \%$ & $2.08 \%$ & $0.07 \%$ \\
\hline + Noninterest income & $1.00 \%$ & $1.00 \%$ & $0.00 \%$ & $1.00 \%$ & $0.00 \%$ \\
\hline = Revenue & $3.02 \%$ & $3.05 \%$ & $0.04 \%$ & $3.08 \%$ & $0.06 \%$ \\
\hline - Operating expense & $1.82 \%$ & $1.82 \%$ & $0.00 \%$ & $1.82 \%$ & $0.00 \%$ \\
\hline$=$ Pretax income & $1.19 \%$ & $1.23 \%$ & $0.04 \%$ & $1.25 \%$ & $0.06 \%$ \\
\hline NET INCOME & $1.01 \%$ & $1.04 \%$ & $0.03 \%$ & $1.06 \%$ & $0.05 \%$ \\
\hline Return on equity & $8.32 \%$ & $8.16 \%$ & $-0.17 \%$ & $8.32 \%$ & $0.00 \%$ \\
\hline
\end{tabular}


Table A 2010 - Impact of CARs on LSR among 40 Representative Banks, year-end 2010

\begin{tabular}{|c|c|c|c|c|c|}
\hline & \multirow[b]{2}{*}{ Before (1) } & \multicolumn{2}{|c|}{ No change in lending spread } & \multicolumn{2}{|c|}{ Change in lending spread } \\
\hline & & After (2) & Change (3) & After (4) & Change (5) \\
\hline Total capital / RWA & $16.41 \%$ & $17.41 \%$ & $1.00 \%$ & & $1.00 \%$ \\
\hline RWA / Total Assets & $63.60 \%$ & $63.60 \%$ & $0.00 \%$ & & $0.00 \%$ \\
\hline Shareholder's equity & $11.65 \%$ & $12.29 \%$ & $0.64 \%$ & & $0.64 \%$ \\
\hline Wholesale funding & $1.27 \%$ & $0.63 \%$ & $-0.64 \%$ & & $-0.64 \%$ \\
\hline $\begin{array}{l}\text { Increase in lending } \\
\text { spread }\end{array}$ & $0.00 \%$ & $0.00 \%$ & & $0.14 \%$ & \\
\hline $\begin{array}{l}\text { Interest income on } \\
\text { loans }\end{array}$ & $1.78 \%$ & $1.78 \%$ & $0.00 \%$ & $1.83 \%$ & $0.05 \%$ \\
\hline $\begin{array}{l}+ \text { Interest income ex } \\
\text { loans }\end{array}$ & $3.35 \%$ & $3.35 \%$ & $0.00 \%$ & $3.35 \%$ & $0.00 \%$ \\
\hline Interest income & $5.13 \%$ & $5.13 \%$ & $0.00 \%$ & $5.18 \%$ & $0.05 \%$ \\
\hline - Interest expense & $3.00 \%$ & $2.97 \%$ & $-0.03 \%$ & $2.97 \%$ & $-0.03 \%$ \\
\hline$=$ Net Interest income & $2.12 \%$ & $2.16 \%$ & $0.04 \%$ & $2.21 \%$ & $0.09 \%$ \\
\hline + Noninterest income & $1.05 \%$ & $1.05 \%$ & $0.00 \%$ & $1.05 \%$ & $0.00 \%$ \\
\hline$=$ Revenue & $3.18 \%$ & $3.21 \%$ & $0.03 \%$ & $3.26 \%$ & $0.08 \%$ \\
\hline - Operating expense & $1.82 \%$ & $1.82 \%$ & $0.00 \%$ & $1.82 \%$ & $0.00 \%$ \\
\hline$=$ Pretax income & $1.36 \%$ & $1.39 \%$ & $0.03 \%$ & $1.43 \%$ & $0.07 \%$ \\
\hline NET INCOME & $1.15 \%$ & $1.18 \%$ & $0.03 \%$ & $1.22 \%$ & $0.06 \%$ \\
\hline Return on equity & $9.91 \%$ & $9.63 \%$ & $-0.28 \%$ & $9.91 \%$ & $0.00 \%$ \\
\hline
\end{tabular}

Table A - 2011 - Impact of CARs on LSR among 38 Representative Banks, yearend 2011

\begin{tabular}{|l|c|c|c|c|c|}
\hline & & \multicolumn{2}{l|}{ No change in lending spread } & \multicolumn{2}{c|}{ Change in lending spread } \\
\cline { 4 - 6 } & Before (1) & After (2) & Change (3) & After (4) & Change (5) \\
\hline Total capital / RWA & $16.19 \%$ & $17.19 \%$ & $1.00 \%$ & & $1.00 \%$ \\
\hline RWA / Total Assets & $65.83 \%$ & $65.83 \%$ & $0.00 \%$ & & $0.00 \%$ \\
\hline Shareholder's equity & $11.89 \%$ & $12.55 \%$ & $0.66 \%$ & & $0.66 \%$ \\
\hline Wholesale funding & $1.59 \%$ & $0.93 \%$ & $-0.66 \%$ & & $-0.66 \%$ \\
\hline & & & & & \\
\hline $\begin{array}{l}\text { Increase in lending } \\
\text { spread }\end{array}$ & $0.00 \%$ & $0.00 \%$ & & & \\
\hline $\begin{array}{l}\text { Interest income on } \\
\text { loans }\end{array}$ & $1.70 \%$ & $1.70 \%$ & $0.00 \%$ & $1.73 \%$ & $0.03 \%$ \\
\hline $\begin{array}{l}\text { + Interest income ex } \\
\text { loans }\end{array}$ & $3.19 \%$ & $3.19 \%$ & $0.00 \%$ & $3.19 \%$ & $0.00 \%$ \\
\hline Interest income & $4.89 \%$ & $4.89 \%$ & $0.00 \%$ & $4.92 \%$ & $0.03 \%$ \\
\hline - Interest expense & $2.94 \%$ & $2.91 \%$ & $-0.03 \%$ & $2.91 \%$ & $-0.03 \%$ \\
\hline = Net Interest income & $1.95 \%$ & $1.98 \%$ & $0.03 \%$ & $2.01 \%$ & $0.06 \%$ \\
\hline + Noninterest income & $1.02 \%$ & $1.02 \%$ & $0.00 \%$ & $1.02 \%$ & $0.00 \%$ \\
\hline = Revenue & $2.97 \%$ & $3.00 \%$ & $0.03 \%$ & $3.04 \%$ & $0.07 \%$ \\
\hline - Operating expense & $1.78 \%$ & $1.78 \%$ & $0.00 \%$ & $1.78 \%$ & $0.00 \%$ \\
\hline = Pretax income & $1.19 \%$ & $1.22 \%$ & $0.03 \%$ & $1.26 \%$ & $0.07 \%$ \\
\hline NET INCOME & $1.01 \%$ & $1.04 \%$ & $0.03 \%$ & $1.07 \%$ & $0.06 \%$ \\
\hline Return on equity & $8.51 \%$ & $8.29 \%$ & $-0.22 \%$ & $8.51 \%$ & $0.00 \%$ \\
\hline
\end{tabular}


Table A-2012 - Impact of CARs on LSR among 39 Representative Banks, yearend 2012

\begin{tabular}{|c|c|c|c|c|c|}
\hline & \multirow[b]{2}{*}{ Before (1) } & \multicolumn{2}{|c|}{ No change in lending spread } & \multicolumn{2}{|c|}{ Change in lending spread } \\
\hline & & After (2) & Change (3) & After (4) & Change (5) \\
\hline Total capital / RWA & $19.97 \%$ & $20.97 \%$ & $1.00 \%$ & & $1.00 \%$ \\
\hline RWA / Total Assets & $63.10 \%$ & $63.10 \%$ & $0.00 \%$ & & $0.00 \%$ \\
\hline Shareholder's equity & $13.50 \%$ & $14.13 \%$ & $0.63 \%$ & & $0.63 \%$ \\
\hline Wholesale funding & $1.71 \%$ & $1.08 \%$ & $-0.63 \%$ & & $-0.63 \%$ \\
\hline $\begin{array}{l}\text { Increase in lending } \\
\text { spread }\end{array}$ & $0.00 \%$ & $0.00 \%$ & & $0.00 \%$ & \\
\hline $\begin{array}{l}\text { Interest income on } \\
\text { loans }\end{array}$ & $1.67 \%$ & $1.67 \%$ & $0.00 \%$ & $1.67 \%$ & $0.00 \%$ \\
\hline $\begin{array}{l}+ \text { Interest income ex } \\
\text { loans }\end{array}$ & $3.13 \%$ & $3.13 \%$ & $0.00 \%$ & $3.13 \%$ & $0.00 \%$ \\
\hline Interest income & $4.80 \%$ & $4.80 \%$ & $0.00 \%$ & $4.80 \%$ & $0.00 \%$ \\
\hline - Interest expense & $3.00 \%$ & $2.97 \%$ & $-0.03 \%$ & $2.97 \%$ & $-0.03 \%$ \\
\hline$=$ Net Interest income & $1.80 \%$ & $1.83 \%$ & $0.03 \%$ & $1.83 \%$ & $0.03 \%$ \\
\hline + Noninterest income & $0.91 \%$ & $0.91 \%$ & $0.00 \%$ & $0.91 \%$ & $0.00 \%$ \\
\hline$=$ Revenue & $2.71 \%$ & $2.74 \%$ & $0.03 \%$ & $2.74 \%$ & $0.03 \%$ \\
\hline - Operating expense & $2.14 \%$ & $2.14 \%$ & $0.00 \%$ & $2.14 \%$ & $0.00 \%$ \\
\hline$=$ Pretax income & $0.57 \%$ & $0.60 \%$ & $0.03 \%$ & $0.60 \%$ & $0.03 \%$ \\
\hline NET INCOME & $0.48 \%$ & $0.51 \%$ & $0.03 \%$ & $0.51 \%$ & $0.03 \%$ \\
\hline Return on equity & $3.57 \%$ & $3.62 \%$ & $+0.05 \%$ & $3.57 \%$ & $0.00 \%$ \\
\hline
\end{tabular}


Table A-2013 - Impact of CARs on LSR among 39 Representative Banks, yearend 2013

\begin{tabular}{|l|c|c|c|c|c|}
\hline & \multirow{2}{*}{ Before (1) } & \multicolumn{2}{l|}{ No change in lending spread } & \multicolumn{2}{c|}{ Change in lending spread } \\
\cline { 3 - 6 } & After (2) & Change (3) & After (4) & Change (5) \\
\hline Total capital / RWA & $20.44 \%$ & $21.44 \%$ & $1.00 \%$ & & $1.00 \%$ \\
\hline RWA / Total Assets & $60.34 \%$ & $60.34 \%$ & $0.00 \%$ & & $0.00 \%$ \\
\hline Shareholder's equity & $12.58 \%$ & $13.18 \%$ & $0.60 \%$ & & $0.60 \%$ \\
\hline Wholesale funding & $1.73 \%$ & $1.13 \%$ & $-0.60 \%$ & & $-0.60 \%$ \\
\hline & & & & & \\
\hline $\begin{array}{l}\text { Increase in lending } \\
\text { spread }\end{array}$ & $0.00 \%$ & $0.00 \%$ & & & \\
\hline $\begin{array}{l}\text { Interest income on } \\
\text { loans }\end{array}$ & $1.69 \%$ & $1.69 \%$ & $0.018 \%$ & \\
\hline $\begin{array}{l}\text { + Interest income ex } \\
\text { loans }\end{array}$ & $3.16 \%$ & $3.16 \%$ & $0.00 \%$ & $3.16 \%$ & $0.00 \%$ \\
\hline Interest income & $4.85 \%$ & $4.85 \%$ & $0.00 \%$ & $4.85 \%$ & $0.01 \%$ \\
\hline - Interest expense & $3.01 \%$ & $2.97 \%$ & $-0.03 \%$ & $2.97 \%$ & $-0.03 \%$ \\
\hline = Net Interest income & $1.84 \%$ & $1.87 \%$ & $0.03 \%$ & $1.87 \%$ & $0.04 \%$ \\
\hline + Noninterest income & $0.90 \%$ & $0.90 \%$ & $0.00 \%$ & $0.90 \%$ & $0.00 \%$ \\
\hline = Revenue & $2.73 \%$ & $2.77 \%$ & $0.03 \%$ & $2.77 \%$ & $0.04 \%$ \\
\hline - Operating expense & $1.91 \%$ & $1.91 \%$ & $0.00 \%$ & $1.91 \%$ & $0.00 \%$ \\
\hline = Pretax income & $0.83 \%$ & $0.86 \%$ & $0.03 \%$ & $0.87 \%$ & $0.04 \%$ \\
\hline NET INCOME & $0.70 \%$ & $0.73 \%$ & $0.03 \%$ & $0.74 \%$ & $0.03 \%$ \\
\hline Return on equity & $5.60 \%$ & $5.56 \%$ & $-0.04 \%$ & $5.60 \%$ & $0.00 \%$ \\
\hline
\end{tabular}

Table A-2014 - Impact of CARs on LSR among 37 Representative Banks, yearend 2014

\begin{tabular}{|l|c|c|c|c|c|}
\hline & \multirow{2}{*}{ Before (1) } & \multicolumn{2}{l|}{ No change in lending spreads } & \multicolumn{2}{c|}{ Change in lending spread } \\
\cline { 3 - 6 } & After (2) & Change (3) & After (4) & Change (5) \\
\hline Total capital / RWA & $21.96 \%$ & $22.96 \%$ & $1.00 \%$ & & $1.00 \%$ \\
\hline RWA / Total Assets & $59.74 \%$ & $59.74 \%$ & $0.00 \%$ & & $0.00 \%$ \\
\hline Shareholder's equity & $13.38 \%$ & $13.97 \%$ & $0.59 \%$ & & $0.59 \%$ \\
\hline Wholesale funding & $1.91 \%$ & $1.32 \%$ & $-0.59 \%$ & & $-0.59 \%$ \\
\hline & & & & & \\
\hline $\begin{array}{l}\text { Increase in lending } \\
\text { spread }\end{array}$ & $0.00 \%$ & $0.00 \%$ & & $0.02 \%$ & \\
\hline $\begin{array}{l}\text { Interest income on } \\
\text { loans }\end{array}$ & $1.69 \%$ & $1.69 \%$ & $0.00 \%$ & $1.70 \%$ & $0.01 \%$ \\
\hline $\begin{array}{l}\text { + Interest income ex } \\
\text { loans }\end{array}$ & $3.18 \%$ & $3.18 \%$ & $0.00 \%$ & $3.18 \%$ & $0.00 \%$ \\
\hline Interest income & $4.87 \%$ & $4.87 \%$ & $0.00 \%$ & $4.88 \%$ & $0.01 \%$ \\
\hline - Interest expense & $3.09 \%$ & $3.06 \%$ & $-0.03 \%$ & $3.06 \%$ & $-0.03 \%$ \\
\hline = Net Interest income & $1.78 \%$ & $1.81 \%$ & $0.03 \%$ & $1.82 \%$ & $0.04 \%$ \\
\hline + Noninterest income & $0.95 \%$ & $0.95 \%$ & $0.00 \%$ & $0.95 \%$ & $0.00 \%$ \\
\hline = Revenue & $2.73 \%$ & $2.76 \%$ & $0.03 \%$ & $2.77 \%$ & $0.04 \%$ \\
\hline - Operating expense & $1.74 \%$ & $1.74 \%$ & $0.00 \%$ & $1.74 \%$ & $0.00 \%$ \\
\hline = Pretax income & $0.99 \%$ & $1.02 \%$ & $0.03 \%$ & $1.03 \%$ & $0.04 \%$ \\
\hline NET INCOME & $0.84 \%$ & $0.87 \%$ & $0.03 \%$ & $0.88 \%$ & $0.04 \%$ \\
\hline Return on equity & $6.27 \%$ & $6.23 \%$ & $-0.04 \%$ & $6.27 \%$ & $0.00 \%$ \\
\hline
\end{tabular}


Table A - 2015 - Impact of CARs on LSR among 36 Representative Banks, year 2015

\begin{tabular}{|l|c|c|c|c|c|}
\hline & \multirow{2}{*}{ Before (1) } & \multicolumn{2}{c|}{ No change in lending spread } & \multicolumn{2}{c|}{ Change in lending spread } \\
\cline { 3 - 6 } & After (2) & Change (3) & After (4) & Change (5) \\
\hline Total capital / RWA & $22.03 \%$ & $23.03 \%$ & $1.00 \%$ & & $1.00 \%$ \\
\hline RWA / Total Assets & $61.82 \%$ & $61.82 \%$ & $0.00 \%$ & & $0.00 \%$ \\
\hline Shareholder's equity & $13.96 \%$ & $14.58 \%$ & $0.62 \%$ & & $0.62 \%$ \\
\hline Wholesale funding & $2.07 \%$ & $1.45 \%$ & $-0.62 \%$ & & $-0.62 \%$ \\
\hline & & & & & \\
\hline $\begin{array}{l}\text { Increase in lending } \\
\text { spread }\end{array}$ & $0.00 \%$ & $0.00 \%$ & & & \\
\hline $\begin{array}{l}\text { Interest income on } \\
\text { loans }\end{array}$ & $1.71 \%$ & $1.71 \%$ & $0.08 \%$ & \\
\hline $\begin{array}{l}\text { + Interest income ex } \\
\text { loans }\end{array}$ & $3.20 \%$ & $3.20 \%$ & $0.00 \%$ & $3.20 \%$ & $0.00 \%$ \\
\hline Interest income & $4.91 \%$ & $4.91 \%$ & $0.00 \%$ & $4.93 \%$ & $0.02 \%$ \\
\hline - Interest expense & $3.19 \%$ & $3.15 \%$ & $-0.04 \%$ & $3.15 \%$ & $-0.04 \%$ \\
\hline = Net Interest income & $1.72 \%$ & $1.76 \%$ & $0.04 \%$ & $1.78 \%$ & $0.06 \%$ \\
\hline + Noninterest income & $1.02 \%$ & $1.02 \%$ & $0.00 \%$ & $1.02 \%$ & $0.00 \%$ \\
\hline = Revenue & $2.74 \%$ & $2.78 \%$ & $0.04 \%$ & $2.80 \%$ & $0.06 \%$ \\
\hline - Operating expense & $1.70 \%$ & $1.70 \%$ & $0.00 \%$ & $1.70 \%$ & $0.00 \%$ \\
\hline = Pretax income & $1.04 \%$ & $1.08 \%$ & $0.04 \%$ & $1.10 \%$ & $0.06 \%$ \\
\hline NET INCOME & $0.90 \%$ & $0.92 \%$ & $0.02 \%$ & $0.94 \%$ & $0.04 \%$ \\
\hline Return on equity & $6.45 \%$ & $6.30 \%$ & $-0.15 \%$ & $6.45 \%$ & $0.00 \%$ \\
\hline
\end{tabular}


Table A - 2016 - Impact of CARs on LSR among 36 Representative Banks, year 2016

\begin{tabular}{|l|c|c|c|c|c|}
\hline & \multirow{2}{*}{ Before (1) } & \multicolumn{2}{c|}{ No change in lending spread } & \multicolumn{2}{c|}{ Change in lending spread } \\
\cline { 4 - 6 } & After (2) & Change (3) & After (4) & Change (5) \\
\hline Total capital / RWA & $20.58 \%$ & $21.58 \%$ & $1.00 \%$ & & $1.00 \%$ \\
\hline RWA / Total Assets & $61.31 \%$ & $61.31 \%$ & $0.00 \%$ & & $0.00 \%$ \\
\hline Shareholder's equity & $13.34 \%$ & $13.95 \%$ & $0.61 \%$ & & $0.61 \%$ \\
\hline Wholesale funding & $2.07 \%$ & $1.46 \%$ & $-0.61 \%$ & & $-0.61 \%$ \\
\hline & & & & & \\
\hline $\begin{array}{l}\text { Increase in lending } \\
\text { spread }\end{array}$ & $0.00 \%$ & $0.00 \%$ & & & \\
\hline $\begin{array}{l}\text { Interest income on } \\
\text { loans }\end{array}$ & $1.70 \%$ & $1.70 \%$ & $0.00 \%$ & $1.71 \%$ & $0.01 \%$ \\
\hline $\begin{array}{l}\text { + Interest income ex } \\
\text { loans }\end{array}$ & $3.12 \%$ & $3.12 \%$ & & & \\
\hline Interest income & $4.82 \%$ & $4.82 \%$ & $0.00 \%$ & $3.12 \%$ & $0.00 \%$ \\
\hline - Interest expense & $2.97 \%$ & $2.94 \%$ & $-0.03 \%$ & $2.94 \%$ & $-0.03 \%$ \\
\hline = Net Interest income & $1.85 \%$ & $1.88 \%$ & $0.03 \%$ & $1.88 \%$ & $0.03 \%$ \\
\hline + Noninterest income & $0.91 \%$ & $0.91 \%$ & $0.00 \%$ & $0.91 \%$ & $0.00 \%$ \\
\hline = Revenue & $2.76 \%$ & $2.79 \%$ & $0.03 \%$ & $2.79 \%$ & $0.03 \%$ \\
\hline - Operating expense & $1.88 \%$ & $1.88 \%$ & $0.00 \%$ & $1.88 \%$ & $0.00 \%$ \\
\hline = Pretax income & $0.88 \%$ & $0.90 \%$ & $0.02 \%$ & $0.91 \%$ & $0.03 \%$ \\
\hline NET INCOME & $0.74 \%$ & $0.76 \%$ & $0.02 \%$ & $0.77 \%$ & $0.03 \%$ \\
\hline Return on equity & $5.54 \%$ & $5.49 \%$ & $-0.05 \%$ & $5.54 \%$ & $0.00 \%$ \\
\hline
\end{tabular}

